memory, and understanding. If one read for disease of the mind, disease of the brain, it would follow that in many cases pleas of insanity would not be established because it could not be proved that the brain had been affected in any way, either by degeneration of the cells or in any other way. In my judgment the condition of the brain is irrelevant, and so is the question as to whether the condition of the mind is curable or incurable, transitory or permanent." With the greater availability of new imaging techniques, however, sustaining a distinction between "mind" and "brain" has become increasingly difficult.

One consequence of the legal view of insanity has been the unnecessary stigmatisation of certain groups - for example, people with epilepsy and sleepwalkers. Another is that defendants who fall within the category of having automatisms must (by act of parliament) be sent to a secure hospital under the control of the Home Secretary, while those who fall into the "sane" category walk out of court free. The judge has no option in this matter. For example, a defendant suffering from an islet cell tumour who offends in a confusional state must be sent to a secure hospital whereas if the confusional state resulted from injected insulin he or she would be given an absolute acquittal.
Although one sympathises with the lawyers' intentions, the law on these two points must be changed. The criminal justice bill now going through parliament provides an ideal opportunity for this. Firstly, the statutory disposal must be altered: the judge should be allowed to decide whether a defendant is given an absolute acquittal, goes to hospital, or is sent to a secure hospital. Secondly, the label of insanity should be abandoned. Both Lord Chief Justice Lane ${ }^{5}$ and Lord Diplock ${ }^{6}$ have said that it is natural to feel reluctance to attach the label of insanity to someone suffering from epilepsy or sleepwalking. Lord Lane agrees with Lord Diplock's view that "It does not lie within the power of the courts to alter it. Only parliament can do that. It has done so twice. It could do so again."

Consultant Psychiatrist,

P B C FENWICK

Institute of Psychiatry,

London SE5 8AF

1 Fenwick PBC. Automatism, medicine and the law. Psychoi Med [Monogr Suppl] 1990;17:1-27. 2 Fenton G. Epilepsy and automatism. Br f Hosp Med 1972;7:57-64

3 Bratty $v$ Attorney General for Northern Ireland. (1983) AC 386, 412 .

$4 \mathrm{R} v \operatorname{Kemp}(1957) 1 \mathrm{QB} 399,407$.

$5 \mathrm{R} v$ Burgess (1991). Unrevised judgment. Court of Appeal, 12 March.

$6 \mathrm{R} v$ Sullivan (1983). House of Lords Weekly Law Reports, July 8th.

\title{
Health targets
}

\section{Time to put the NHS back on course}

Tall ships will be visiting the United Kingdom this summer; so too perhaps tall stories. When navigating a dangerous passage in stormy weather helmsmen lash themselves to the wheel. But in these days of tempest in the NHS one might wonder whether the fleet is scattering in all directions because no course has been set. Organisations lacking a clear vision of their future and an obsession with winning are unlikely to survive, let alone succeed. ${ }^{1}$ All the more important then for those who sail in the NHS to know where they are going and to chart their progress accurately. Saying that we are concerned with improving health is not enough; we must set measurable objectives for health gain, monitor our progress, and take corrective action if we deviate from our course.

Next week the government is due to publish a consultative document on a national health strategy for England. According to William Waldegrave, Secretary of State for Health, it will give the NHS a clear set of goals against which to set its priorities and measure success. ${ }^{2}$ This should be applauded, not least because it will provide guidance for action by other government departments whose policies may have a profound impact on health - for example, on tobacco taxation, food supply, sex education, and housing. The draft strategy is likely to be based on the World Health Organisation's Targets for Health for All drawn up by WHO's European office. ${ }^{3}$ So far, more than 10 countries have followed WHO's lead in setting quantifiable health objectives.

Until this initiative the British government had been slow to set measurable health objectives with timetables, which has not gone unnoticed by the opposition parties. The Social and Liberal Democrats have advocated a comprehensive strategy of health promotion based on the WHO targets. Labour has gone further in its National Health initiative, and Robin Cook, Labour's shadow health secretary, has already put forward a set of priority targets. While England has taken its time, however, progress has been faster elsewhere in the
United Kingdom. Scotland has recently set some health targets for the under $65 \mathrm{~s}$ by the year $2000,{ }^{4}$ and Northern Ireland has published a consultative document.

Wales has by far the longest experience of this. In 1985 targets were set for the United Kingdom's first regional heart disease prevention programme, Heartbeat Wales. ${ }^{6}$ Then in January last year Peter Walker, as secretary of state, launched an ambitious strategy of "Health for All in Wales" to "take Wales into the 21 st century with a level of health on course to compare with the best in Europe." This included targets grouped under disease prevention, healthy lifestyles, health skills, and healthy environments. ${ }^{7}$ Spliced into this initiative has been a major development within the NHS itself. The director for Wales, John Wyn Owen, leads a health planning forum, which has devised a new framework for the NHS in Wales. With the active support of the new Secretary of State for Wales, David Hunt, a series of carefully constructed protocols for investment are being published for the 10 priority subjects (for example, cancer and cardiovascular disease). These will conclude with a series of targets across health care, ranging from prevention to rehabilitation. ${ }^{8}$

When considering our response to the government's new draft strategy we need to consider the effectiveness of the approach of setting targets as well as the specific proposals themselves. Could targets for health reorient the NHS towards outcome? Do they inspire, motivate, and encourage coordination and common purpose among health care workers and organisations? Can they engage other sectors at local and national levels? Will they mobilise support from ordinary people and communities?

Experience from the United States over more than a decade can help us here. In 1979 the Surgeon General published his seminal report Healthy People, ${ }^{9}$ which was expanded in 1980 with Objectives for the Nation, setting out 226 targets for 1990 in 15 priority subjects. ${ }^{10} \mathrm{~A}$ mid-course review was carried out, 
and by 1987 half the targets had been achieved." Clearly, establishing and tracking measurable national objectives helped to form a national health agenda and identify explicit health policies. It also identified issues where further attention was needed. ${ }^{12}$

Building on this progress, the Americans have recently published their objectives for the year $2000 .^{13}$ Twenty two priorities are presented under three overarching goalsincreasing healthy life span, reducing disparities in health, and improving access to services. What is impressive is how these targets have been formulated. Work began in 1987 with the convening of a consortium, which now includes 300 national organisations. Some 10000 people were consulted, and 750 discrete responses have been received. The American targets therefore do not reflect the views of just one organisation but are rather the product of a national process. Such participation is vital for there to be a real sense of ownership and common purpose.

The quality of their work is also impressive. Figures are not plucked from the sky but are founded on careful analysis of trends, opportunities, and challenges - an approach that Wales has also been following. Nor are targets merely set where information to monitor them already exists: if a subject is important enough for an objective to be proposed then a method of monitoring it must be found.

New Zealand provides another case study. Health goals and targets are being used to reorient the health system systematically "to provide a focus and direction." "Goal and target setting is a basic pre-condition to effective management and is the basis for accountability for both the use of health resources and for achieving health care outcomes." incorporated into contracts with area health boards.

For health targets to cascade through the NHS, regional and district health authorities will need to draw on a set of new skills and invest in more monitoring of health states. Public health medicine has a unique part to play, and already the faculty has developed an initiative on "United Kingdom levels of health." This will be reported in June and should give guidance on methods and approaches as well as recommending valid indicators of health and suggesting targets. Another important task will be to identify missing information on the health of the nation as the common dataset for public health is patchy. ${ }^{15}$

There has probably never been a better moment for the United Kingdom to develop and implement a comprehensive national health strategy using targets to provide direction and pace. There is all party support, the offer of help from the Faculty of Public Health Medicine, and considerable experience to draw on from within the United Kingdom and overseas. Our NHS, which has so many good things about it, has another opportunity to lead.

Professor of Health Promotion,

JOHN C CATFORD

Institute for Health Promotion,

School of Public Health,

University of Wales College of Medicine,

Cardiff CF2 1EB

1 Hamel G, Prahalad CK. Strategic intent. Harvard Business Review 1989;67:63-76.

2 Waldegrave W. House of Commons official report (Hansard) 1991 January 16;183:col 873-82.

World Health Organisation Regional Office for Europe. Targets for health for all. Copenhagen: WHO, 1985.

Scottish Office Home and Health Department. Health education in Scotland-a national policy statement. Edinburgh: HMSO, 1991

Northern Ireland Health Promotion Agency. Health promotion in Northern Ireland. A discussion paper. Belfast: Northern Ireland Health Promotion Agency, 1990.

Health Promotion Authority for Wales. Take heart: a consultative document on the development of community based heart health initiatives within Wales. Cardiff: Health Promotion Authority for Wales, 1985. (Heartbeat report No 1.)

Health Promotion Authority for Wales. Health for all in Wales: health promotion challenges for the 1990's. Cardiff: Health Promotion Authority for Wales, 1990

1990 's. Cardiff: Health Promotion Authority for Wales, 1990.
Welsh Health Planning Forum. Strategic intent and directions for the NHS in Wales. Cardiff: Welsh Welsh Health Planning Forum. Stat
Office NHS Directorate, 1989.

9 US Public Health Service. Healthy people. Surgeon General's report on health promotion and disease prevention. Washington, DC: US Department of Health and Human Services, 1979.

10 US Public Health Service. Promoting health/preventing disease: objectives for the nation. Washington, DC: US Department of Health and Human Services, 1980.

1 US National Center for Health Statistics. Health, United States, 1989 and prevention profile. Hyattsville, MD: US Department of Health and Human Services, 1990. ((PHS) 90-1232.)

12 McGinnis JM. Setting objectives for public health in the 1990s: experience and prospects. Ann Rev Public Health 1990;11:231-49.

13 US Public Health Service. Healthy people: national health promotion and disesae prevention objectives. Washington, DC: US Department of Health and Human Services, 1991.

14 New Zeaiand Government. A new relationship (includes New Zealand health goals and targets, health charter, and a contract for area health boards). Wellington: New Zealand Government Printing, charter, 1989.

15 Department of Health. Public health common data set 1990. London: HMSO, 1990

\section{Tissue generation of angiotensin I and II changes the picture}

The renin-angiotensin system plays an important part in cardiovascular homoeostasis through the actions of angiotensin II on target organs such as the kidneys, the blood vessels, and the adrenals.' Standard teaching is that renin secreted by the kidney acts on circulating angiotensinogen produced by the liver to release angiotensin I; this is converted to the active angiotensin II by angiotensin converting enzyme (ACE), mainly in the pulmonary circulation.

This classic concept has been challenged by several recent observations that suggest that the primary site of generation of both angiotensin I and II may not be in the circulation but in tissues and that the vital step in the cascade may not be the delivery of angiotensin II but the delivery of renin and angiotensinogen to tissues. ${ }^{23}$ Angiotensin II would then be formed locally. Further recent research has shown the presence of messenger RNA for renin ${ }^{45}$ and angiotensinogen ${ }^{6}$ in a wide variety of tissues - indicating that both may also be locally synthesised. Such locally synthesised components might interact with components derived from the circulation and critically determine the amount of tissue angiotensin II being generated. The overall effect of the system would then result from the sum of local generation of angiotensin II at multiple sites, each of which could be differently regulated.

This revised concept has important implications for our understanding of the role of the renin-angiotensin system in hypertension. In particular, it suggests that the concentrations of circulating renin and angiotensin II may not accurately reflect the activity of the system in this condition. Although there is no evidence to suggest selective uptake of renin or angiotensinogen into tissues in any form of hypertension, angiotensin converting enzyme activity has been found to be raised in vascular tissue in at least one model of renovascular hypertension at a stage when the circulating renin level is falling. ${ }^{7}$ This raised activity may play some part in maintaining the hypertension.

Increasing evidence is also accumulating that in various forms of hypertension locally synthesised tissue renin may also be important. Thus concentrations of renin messenger RNA have been found to be raised in several tissues in rats with spontaneous hypertension - a recognised genetic model ${ }^{8}$ - and in the adrenal glands of rats with chronic renovascular hypertension. ${ }^{9}$ Even more dramatic evidence has recently 